\title{
Implementasi FingerPrint dan Short Message Service Gateway pada Sistem Presensi
}

\author{
Rakhmat Purnomo ${ }^{1,{ }^{*}}$, Ahmad Fudholi ${ }^{1}$ \\ 1 Teknik Informatika; Universitas Bhayangkara Jakarta Raya; Jl. Raya Perjuangan, \\ Marga Mulya, Bekasi Utara, Jawa Barat 17122, Telp:021-88955882, e-mail: \\ rakhmat.purnomo@dsn.ubharajaya.ac.id, ahmad.fudholi@gmail.com \\ * Korespondensi: e-mail: rakhmat.purnomo@dsn.ubharajaya.ac.id
}

\begin{abstract}
The research aims to apply the fingerprint and Short Message Service technology in the attendance system. Presence or attendance is an important activity in the lecturing process. SMK Global Teknologi has a problem in the student attendance data. The human error factor in captured student attendance is a problem in itself. On the other hand there are cases of students who went to school but did not arrive at school to become complaints from parents. Fingerprint technology has been proven to be able to validate someone as proof of attendance, while the SMS gateway is proven to be a reliable telecommunications technology for data communication. The research method used was to conduct observations at the SMK Global Technologi. The interview method was carried out with the principal, representatives of parents, teachers, and students. The system development method used is Waterfall which consists of the stages of planning, analysis, design, finally implementation. The testing method used black-box. The results of the research are the application of student attendance information systems with an attendance system indicator that has been integrated between parents, teachers, homeroom teachers. So that student attendance data can be directly known.
\end{abstract}

Keywords: Attendance System, Fingerprint, SMS Gateway

\begin{abstract}
Abstrak
Tujuan penelitian ini untuk menerapkan teknologi fingerprint dan Short Message Service (SMS) dalam sistem presensi. Presensi atau kehadiran merupakan kegiatan yang penting dalam proses pembelajaran. SMK Global Teknologi memiliki masalah dalam data presensi siswanya. Faktor kesalahan manusia dalam merekap kehadiran siswa menjadi masalah tersendiri. Disisi lain adanya kasus peserta didik yang berangkat ke sekolah tetapi tidak sampai kesekolah menjadi keluhan orang tua. Teknologi fingerprint telah terbukti dapat memvalidasi seseorang sebagai bukti kehadiran, sedangkan SMS gateway terbukti untuk sebagai teknologi telekomunikasi yang handal untuk komunikasi data. Metode penelitian yang digunakan adalah dengan melakuan observasi di SMK Global Teknologi. Metode wawancara dilakukan kepada kepala sekolah, perwakilan orang tua, guru, dan siswa. Metode pengembangan sistem yang digunakan adalah Waterfall yang terdiri dari tahapan perencanaan, analisis, perancangan, dan penerapan. Metode pengujian menggunakan black-box. Hasil dari penelitian ini adalah diterapkannya sistem informasi kehadiran peserta didik dengan indikator sistem kehadiran sudah terintegrasi antara orang tua, guru, wali kelas. Sehingga data kehadiran siswa dapat secara langsung diketahui.
\end{abstract}

Kata kunci: Sistem Kehadiran, Fingerprint, SMS Gateway

\section{Pendahuluan}

Presensi merupakan sebuah kegiatan pengambilan data guna mengetahui jumlah kehadiran pada suatu kegiatan (Sektiawan, 2016). Setiap kegiatan yang akan membutuhkan informasi peserta tentu akan melakukan presensi (Purnomo, Priatna, \& Fathurrozi, 2019). Hal ini 
Submitted: 12 Desember 2020; Revised: 26 Desember 2020; Accepted: 9 Januari 2020; Published: 25 Januari 2020

terjadi juga pada proses pembelajaran. Kegunaan presensi ini terjadi pada pihak pelajar dan pihak pengelola proses belajar mengajar. Dalam arti yang sebenarnya presensi merupakan kehadiran seseorang di tempat kerjanya pada saat mereka harus bekerja. presensi tidak hanya berlaku untuk keryawan ataupun pegawai, presensi juga berlaku untuk pelajar atau siswa sekolah. Dalam proses pembelajaran, seorang guru atau pengajar harus mengetahui namanama siswa yang hadir maupun yang tidak hadir, maka itu guru harus melakukan presensi terhadap siswa di dalam kelas dengan mencatat keterangan kehadiran siswa pada buku presensi dan melakukan rekap dari buku presensi.

SMK Global Teknologi merupakan sekolah yang masih menggunakan pendataan kehadiran siswa dengan cara menulis diatas buku presensi. Guru memeriksa kehadiran siswa sebelum pelaksanaan pembelajaran dilakukan dalam kelas. Setelah pembelajaran berakhir, guru piket akan merekap kehahadiran siswa setiap hari. Kemudaian guru piket akan melakukan rekap. Di akhir semester, guru piket akan memberikan data tersebut ke wali kelas. Begitu seterusnya kegiatan aktivitas presensi.

SMK Global Teknologi memili 550 siswa. Siswa tersebut dibagi menjadi dua jurusan, yaitu Teknik kendaraan Ringan dan Akuntansi. Gambar 1 menunjukan distribusi jumlah siswa.

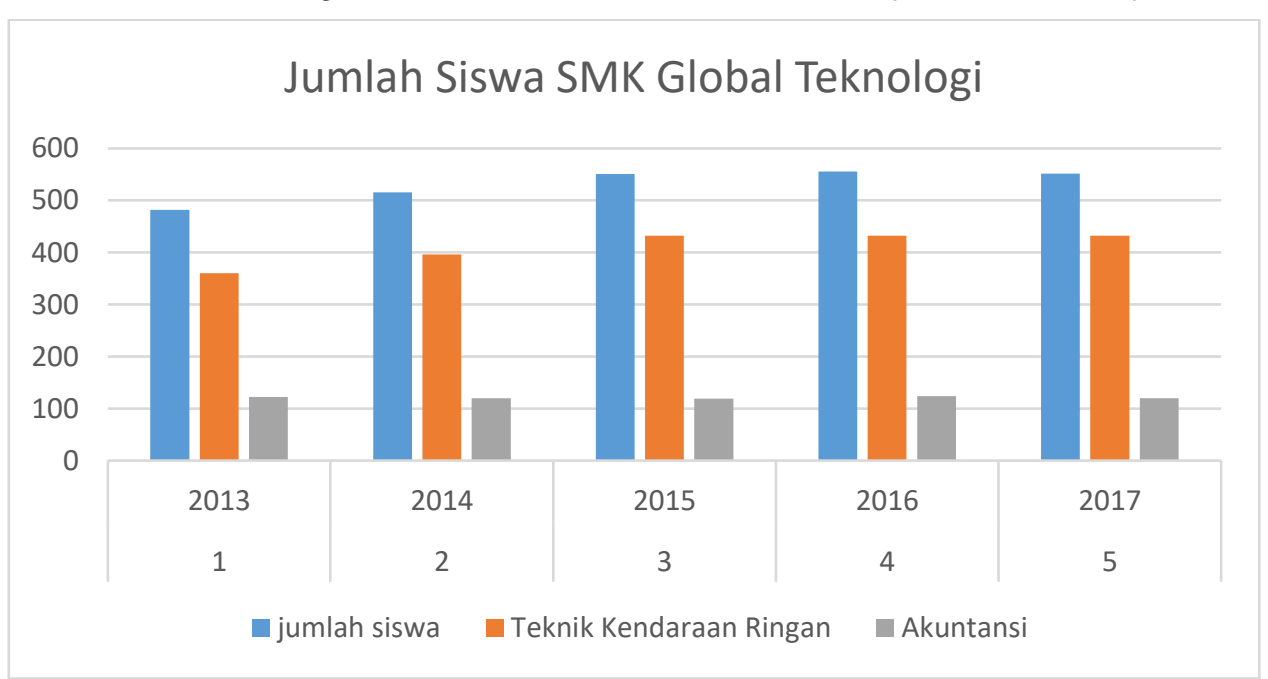

Sumber: Hasil Penelitian (2020)

$$
\text { Gambar 1. Jumlah siswa SMK Global Teknologi }
$$

Banyaknya jumlah siswa menyulitkan jika presensi dilakukan dengan proses yang telah dijelaskan. Orang tua juga tidak dapat memonitor anaknya secara langsung setiap hari. Manajemn sekolah sering mendapati laporan orang tua melalui wali kelasnya bahwa anaknya berangkat ke sekolah tetapi tidak sampai sekolah. Inilah permasalah lain yang ditemukan.

Informasi kehadiran peserta didik merupakan hal yang penting diketahui oleh semua pihak. Orang tua, wali kelas, guru mata pelajaran, dan manajemen sekolah. Informasi merupakan hasil dari pemrosesan data yang diperoleh dari setiap elemen sistem (Purnomo \& Arisandi, 2019). Informasi harus mudah dipahami dan menjadi sumber utama pengetahuan. Informasi merupakan hasil olah fakta - fakta yang ada. Informasi yang baik harus tepat waktu, benar, dan tepat pada waktunya. 
SMS (Short Message Service) merupakan teknologi yang bersifat non-real time, artinya sebuah pesan yang dikirim ke tujuan tidak memperdulikan apakah tujuan tersebut aktif atau tidak (Supriyono, Kurnianto, \& Fikri Khaidir, 2018). SMS diprakarsai oleh European Telecomunication Standards Institute (ETSI) dalam dokumen GSM 3.4 dan GSM 3.38 yang bisa berisi text sampai diatas 160 karakter. Setiap karakter dihitung dengan nilai 7 bit.

Sedangkan SMS Gateway diartikan sebagai penghubung untuk lalulintas data - data SMS, baik yang dikirim maupun yang diterima. Gambar 2 menunjukan alur model SMS Gateway.

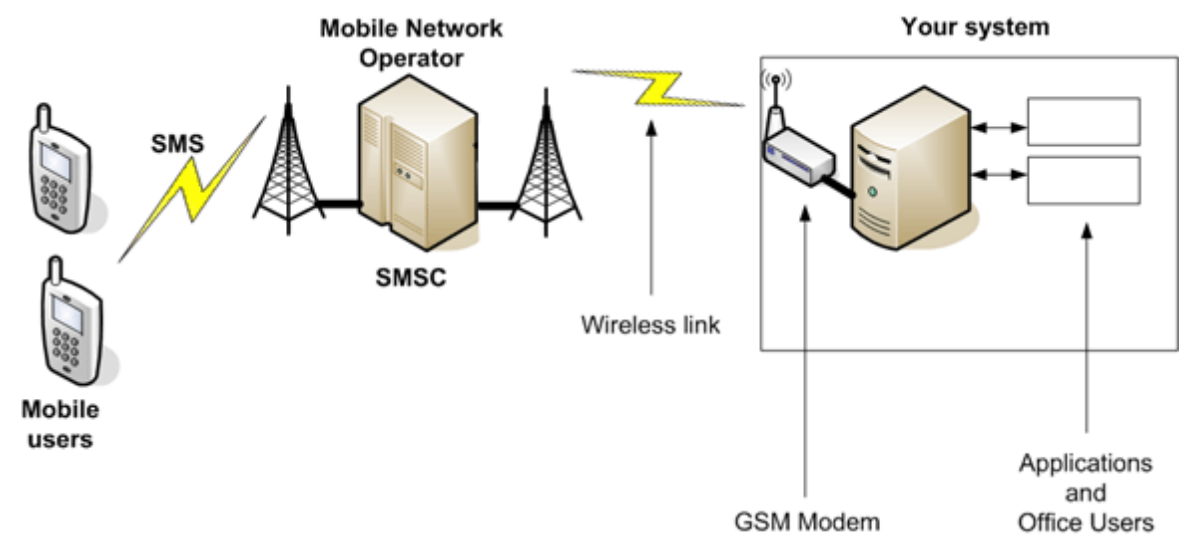

Sumber: https://www.kompasiana.com/andi301/552a1d8f6ea8345005552d0b/aplikasi-sms-gateway-di-kampus Gambar 2. Alur Model SMS Gateway

Pada gambar 2, dapat terlihat infrastruktur dari SMS Gateway. Aplikasi SMS gateway akan mengetahui network setiap operator yang digunakan. Setelah itu akan langsung meneruskan ke aplikasi yang ada. Client membutuhkan modem GSM untuk menjalankan aplikasi sehingga dapat menerima data - data yang dikirimkan oleh operator.

Semua permintaan dari pengguna juga akan diproses oleh aplikasi dan diteruskan oleh SMS gateway agar dapat diterima dan dilakukan pemrosesan data, dan permintaan dari pengguna juga akan dapat diterima hasilnya. Aplikasi SMS gateway membutuhkan akses database sehingga permintaan dari pengguna dapat tersimpan dan dapat diketahui hasilnya. Database berguna untuk menyimpan transaksi setiap saat. Permintaan tersebut akan di proses dan diketahui permintaan terbanyak yang terjadi dalam suatu transaksi.

Indentitas sesorang dapat diketahui dengan menggunakan sidik jari. teknologi ini dikenal dengan istilah fingerPrint (Munir, Javed, \& Khan, 2012). Setiap orang memiliki guratan jari tangan berupa garis. la berfungsi untuk memberikan gaya gesek agar benda yang di pegang tidak jatuh. Dengan fingerPrint setiap manusi aberbeda.

\section{Metode Penelitian}

Penelitian ini dilakukan di SMK Global Teknologi di Kabupaten Bekasi. Peserta didik SMK Global Teknologi menempuh pendidikan selama tiga tahun. Terdapat dua jurusan, yiatu Teknik Kendaraan Ringan (otomotif) dan Akuntansi. SMK Global Teknologi berdiri sejak 1 Desember 2008. 
Metode Penelitan dapat dilihat pada gambar 3. Pada gambar 3, tahapan awala adalah mengidentifikasi permasalah kehadiran. Proses ini dilakukan dengan melakukan wawancara dan observasi ke SMK Global Teknologi. Leteratur juga di kaji untuk menentukan ilmu pengetahuan dan teknologi apa yang tepat digunakan untuk menyelesaikan masalah tersebut.

Metode pengembangan sistem yang digunakan adalah waterfall. Metode waterfal terdiri dari tahapan, (1) analisis, (2) Desain, (3) Penulisan Kode Program, (4) Pengujian, dan (5) Penerapan dan Pemeliharaan. Analisis dilakukan dengan melakukan wawancara dan observasi. Sedangkan tahapan desain antarmuka langsung menggunakan kode html. Setelah itu, bahasa pemograman PHP dan database MySQL digunakan untuk menuliskan kode program. Pengujuian menggunakan black box. Terakhir, sistem ini diterapkan pada SMK Global Teknologi.

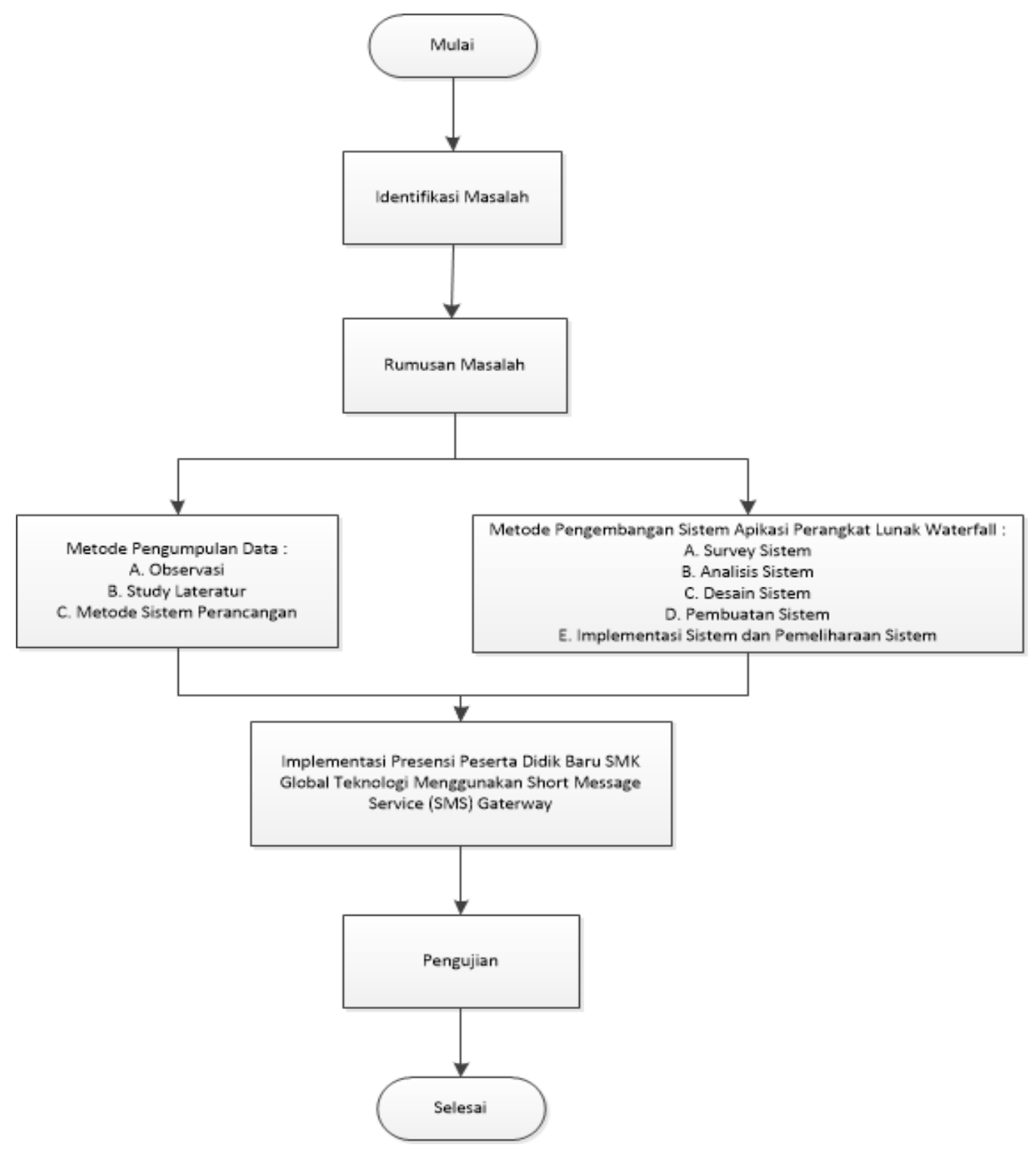

Sumber: Hasil Penelitian (2020)

Gambar 3. Tahapan Penelitian 


\section{Hasil dan Pembahasan}

Hasil pada tahap analisis berupa kondisi apa adanya proses kehadiran di SMK Global Teknologi. Gambar 4 menunjukan analisis sistem berjalan.

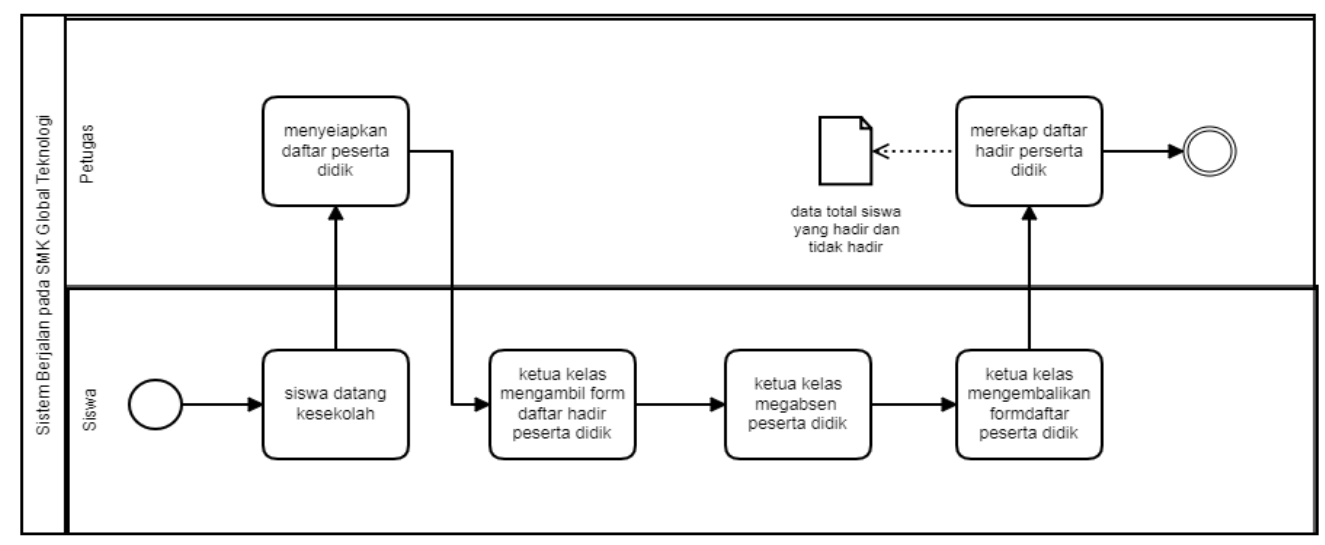

Sumber: Hasil Penelitian (2020)

\section{Gambar 4. Analisis Sistem Berjalan}

Gambar 4 menunjukan permasalahan pada proses kehadiran dimana belum terdapat sistem untuk mengolah data kehadiran peserta didik. Kepala sekolah juga tidka mengetahui data peserta didik. Orang tua siswwa juga terlambat dalam mendapatkan informasi kehadiran anak anaknya. Informasi perkembangan anaknya baru dapat diperoleh saat pengambilan raport.

Sistem yang diusulan terlihat pada gambar 4. Pada gambar 4, peserta diddit datang kesekolah kemudian melakukan fingerprint yang telah disediakan. Data tersebut akan masuk ke dalam database dan di tampilkan dalam Web sistem. Admin kehadiran akan memeriksa data tersebut. Jika data peserta didik valid maka sistem akan mengirimkan informasi melalui SMS kepada orang tua dan wali kelas.

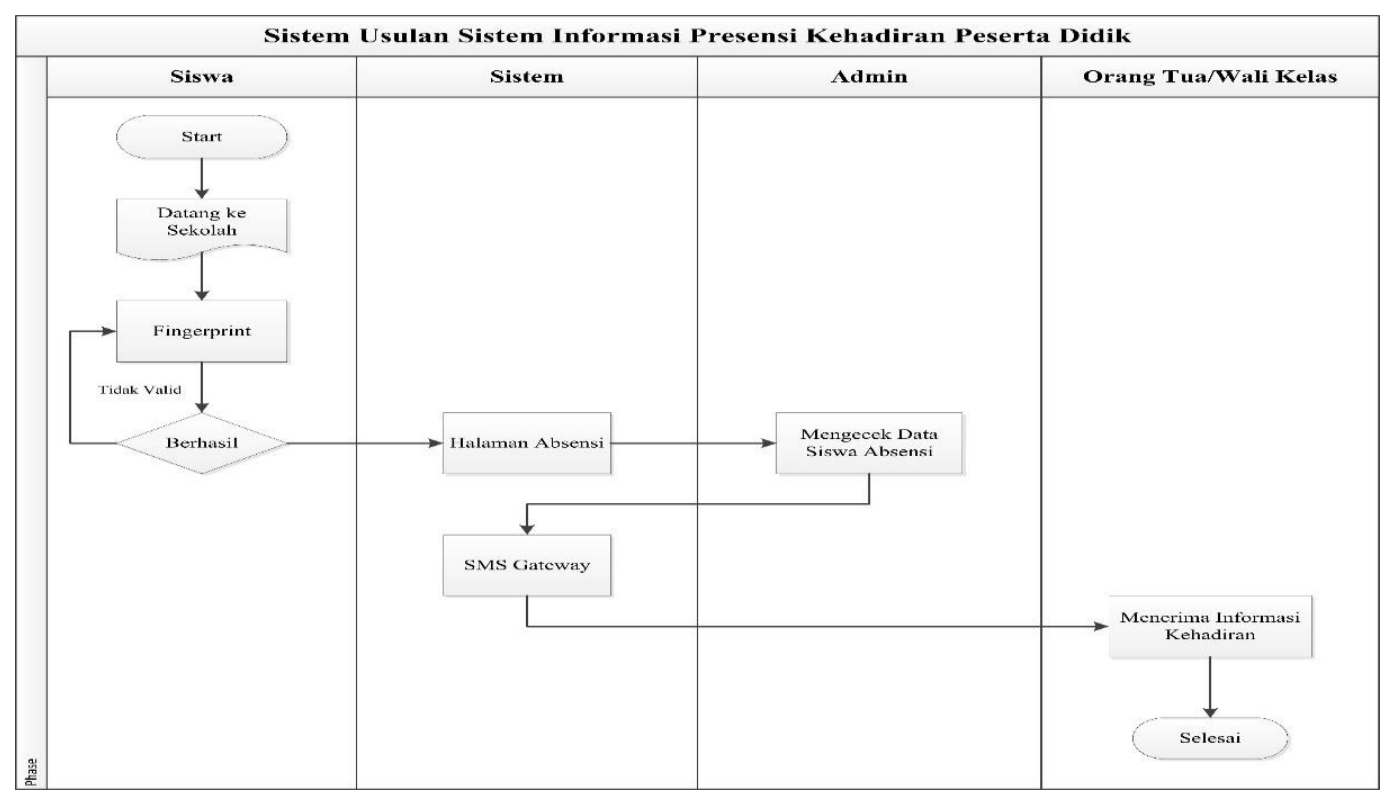

Sumber: Hasil Penelitian (2020)

Gambar 5. Sistem yang diusulkan 
Hasil tahap desain berupa diagram usecase yang ditampilkan pada gambar 6. Gambar 6 menjelaskan 2 aktor yang dapat beriteraksi dalam sistem, yaitu siswa dan admin. Siswa hanya melakukan fingerprit sedangkan admin dapat mengelola seluruh aktivitas kehadiran, antara lain kelolda data SMS, data absensi, laporan, kotan, dan pengaturan keseluruhan sistem.

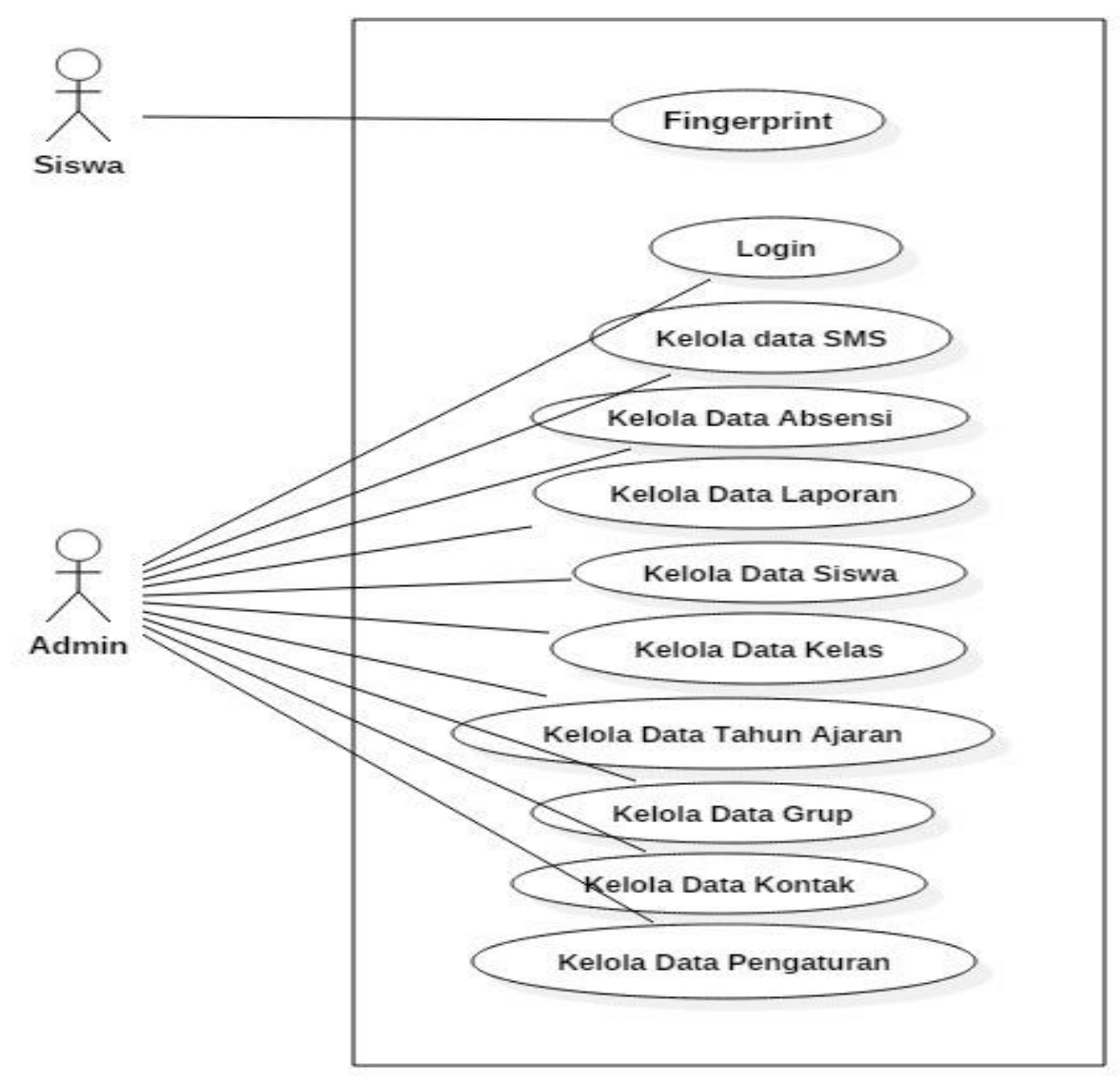

Sumber: Hasil Penelitian (2020)

Gambar 5. Diagram UseCase

Setelah mendefinisikan interaksi antara aktor dengan sistem, disusun diagram aktivitas untuk melihat lebih lengkap aktivitas setiap usecase. Pada kasus ini akan ditampilkan salah satu aktivitas utama sistem yaitu aktivitas kelola data SMSGateway. Gambar 6 menunjukan aktivitas kelola data SMSGateway oleh admin. Untuk dapat mengakses halaman kelola data SMSGateway admin memilih menu SMSGateway kemudian pilih sub menu SMSGateway pada halaman utama web admin. Sistem akan menampilkan menu SMSGateway. Admin dapat mengelola data SMSGateway yaitu, SMS Masal, dan SMS Grup data pada halaman data SMSGateway kemudian sistem akan mengiririm data SMS ke nomor yang dituju.

Selanjutnya diperlukan diagram Sequence untuk memudahkan dalam pengkodean program. Gambar 7 menunjukan Diagram Sequence untuk Kelola data SMSGateway. Pada gambar 7 terliha aktor admin membuka antarmuka halaman utama, kemudian diklik halaman SMS, data di inputkan dan akan tersimpan ke dalam database. 


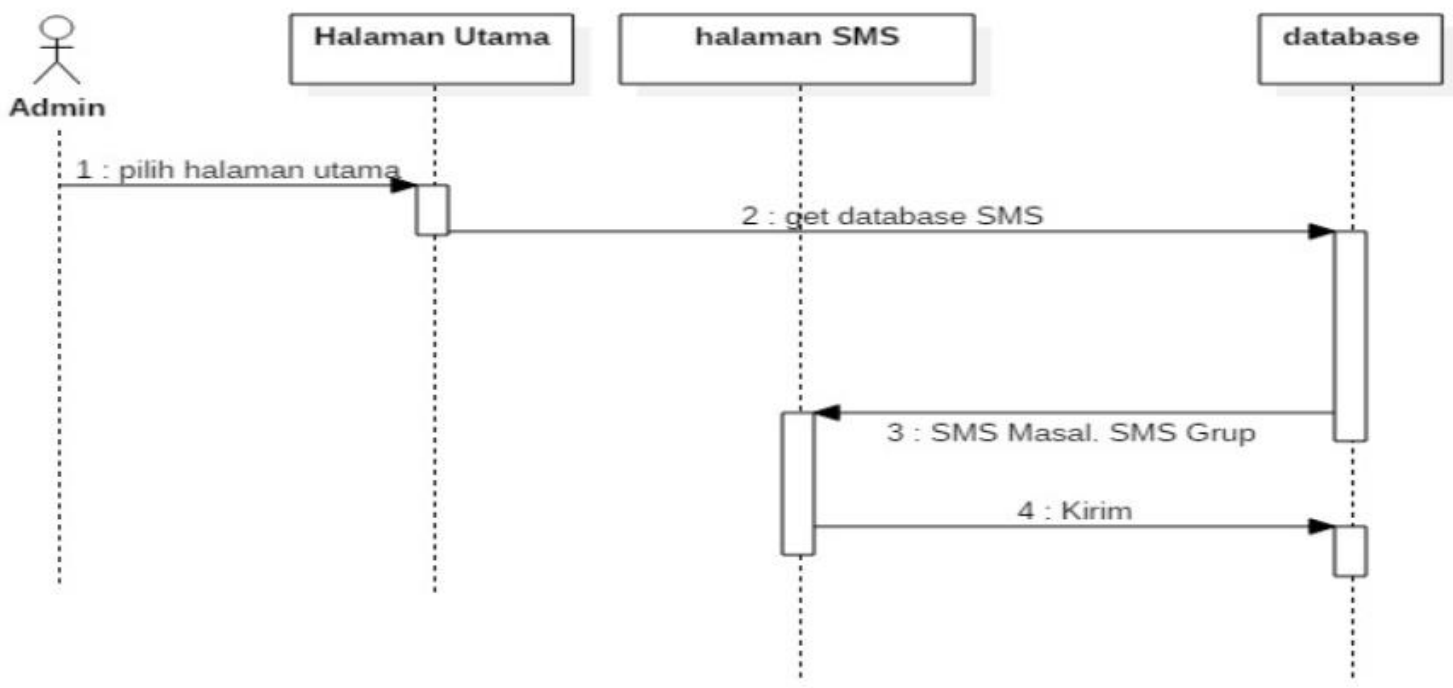

Sumber: Hasil Penelitian (2020)

Gambar 7. Diagram Sequence

Desain database dilihat pada gambar 8. Rancangan database menggunakan data model.

Pada gambar 8 terlihat tabel login, tahun ajaran, grup, admin, kelas, kontak, absen, dan siswa. Setiap entitas memiliki atribut masing - masing.

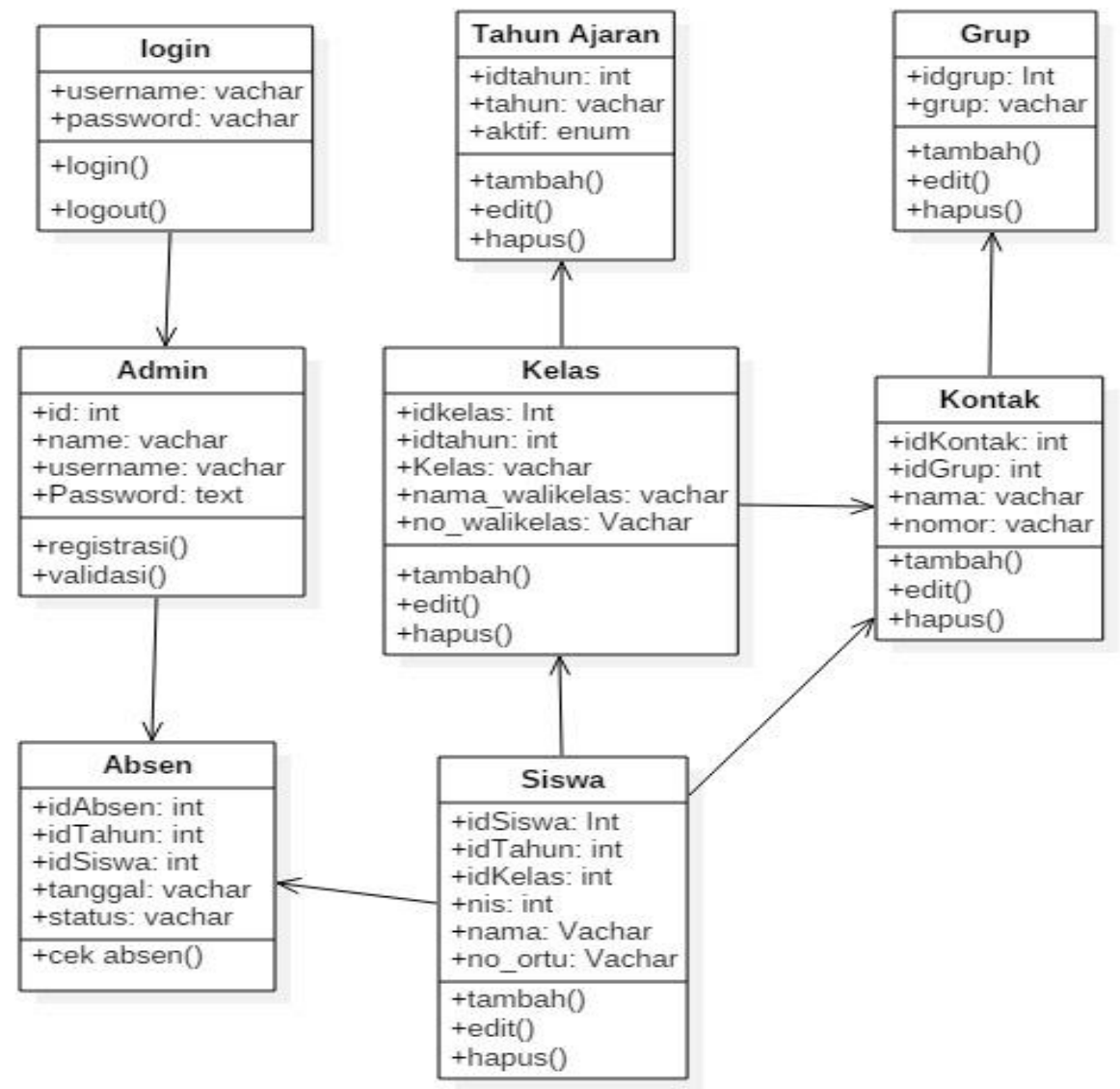

Sumber: Hasil Penelitian (2020)

Gambar 8. Data Model 
Tahap selanjutnya dilakukan pengkodean menggunakan bahasa pemogrmaan php dan database MySQL. Gambar 9 menunjukan antarmuka awal dimana aktor harus melakukan login untuk dapat masuk ke sistem.

\section{O Masuk Sistem}

\section{Masuk}

Sumber: Hasil Penelitian (2020)

Gambr 9. Login ke sistem

Setelah proses login berhasi maka akan masuk ke halaman utama sistem. Gambar 10 menjukan halaman utama sistem. Di halaman utama, aktor dapat melakukan fungi antara lain kelaola data absensi, membuat laporan, kelola data sisw, kelas, grup, dan lainnya.

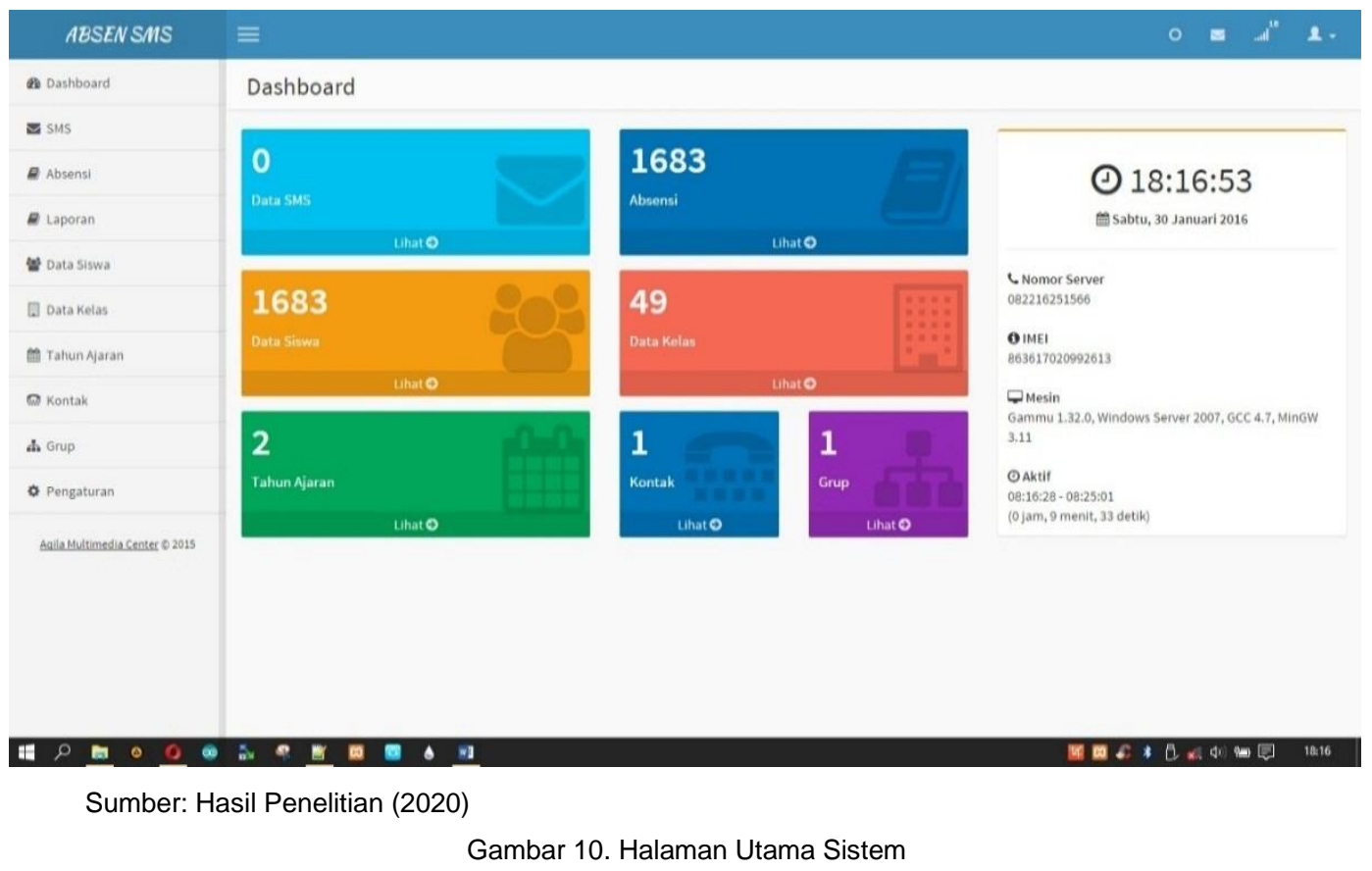

Spesifikasi Perangkat Keras yang digunakan untuk penerapan sistem ini dapat dilihat pada tabel 2. Tabel 2 memperlihatakan kebutuhan minimum dari prosesor, memori, hardisk, monitor, dan alat fingerprint. Perangkat lunak yang digunakan Microsoft Windows 7 sebagai sistem operasinya. 
Tabel 2. Spesifikasi Perangkat keras

\begin{tabular}{ll}
\hline Perangkat keras & Keterangan \\
\hline Processor & $2.50 \mathrm{GHz}$ \\
\hline Memory & DDR2 4 GB \\
\hline Hardisk & $250 \mathrm{~GB}$ \\
\hline Monitor & Resolusi 1152x864 \\
\hline Maouse & Optic 1 buah \\
\hline Modem & 1 Buah \\
\hline Alat fingerprint & Sotion x100-c \\
\hline
\end{tabular}

Sumber: Hasil Penelitian (2020)

Pengujian sistem dilakukan dengan menggunakan metode black-box (Apriliani, Wiyono, \& Mahardhika, 2018). Tabel 3 menunjukan hasil pengujian sistem. Terlihat bahwa hasil pengujian dari setiap skenario pengujian berjalan dengan baik.

Tabel 3. Pengujian Sistem

\begin{tabular}{|c|c|c|c|c|}
\hline No & Fitur & Skenario Pengujian & Hasil Yang Diharapkan & $\begin{array}{c}\text { Hasil } \\
\text { Pengujian }\end{array}$ \\
\hline 1. & $\begin{array}{l}\text { Fungsi Login } \\
\text { Admin }\end{array}$ & $\begin{array}{l}\text { Admin melakukan login dengan } \\
\text { input username dan password }\end{array}$ & $\begin{array}{l}\text { Admin dapat masuk ke dalam sistem } \\
\text { web admin }\end{array}$ & OK \\
\hline 2 & $\begin{array}{l}\text { Fungsi data } \\
\text { SMS }\end{array}$ & $\begin{array}{l}\text { Admin melakukan inpiut data } \\
\text { SMS }\end{array}$ & $\begin{array}{l}\text { Admin dapat mengirim SMS keorang } \\
\text { tua }\end{array}$ & $\mathrm{OK}$ \\
\hline 3 & $\begin{array}{l}\text { Fungsi Input } \\
\text { Data Absensi }\end{array}$ & $\begin{array}{l}\text { Admin melakukan input data } \\
\text { Absensi }\end{array}$ & $\begin{array}{l}\text { Admin dapat mengecek jumlah siswa } \\
\text { perkelas yang tidak masuk }\end{array}$ & $\mathrm{OK}$ \\
\hline 4 & Input Laporan & $\begin{array}{l}\text { Admin melakukan pengecakan } \\
\text { jumlah siswa di data laporan }\end{array}$ & $\begin{array}{l}\text { Admin dapat mengeprint hasil data } \\
\text { laporan }\end{array}$ & $\mathrm{OK}$ \\
\hline 5 & $\begin{array}{l}\text { Input Data } \\
\text { Siswa }\end{array}$ & $\begin{array}{l}\text { Admin melakukan input data } \\
\text { Siswa }\end{array}$ & $\begin{array}{l}\text { Admin dapat menambah, mengedit, } \\
\text { dan menghapus data siswa }\end{array}$ & $\mathrm{OK}$ \\
\hline 6 & $\begin{array}{l}\text { Kelola Data } \\
\text { kelas }\end{array}$ & $\begin{array}{l}\text { Admin melakukan input data } \\
\text { kelas }\end{array}$ & $\begin{array}{l}\text { Admin dapat menambah, mengedit, } \\
\text { dan menghapus data kelas }\end{array}$ & OK \\
\hline 7 & $\begin{array}{l}\text { Input Data } \\
\text { Tahun Ajaran }\end{array}$ & $\begin{array}{l}\text { Admin melakukan input data } \\
\text { tahun ajaran }\end{array}$ & $\begin{array}{l}\text { Admin dapat menambah, mengedit, } \\
\text { dan menghapus data tahun ajaran }\end{array}$ & OK \\
\hline 8 & $\begin{array}{l}\text { Kelola Data } \\
\text { Kontak }\end{array}$ & $\begin{array}{l}\text { Admin melakukan input data } \\
\text { kontak }\end{array}$ & $\begin{array}{l}\text { Data kontak dapat ditambahkan, } \\
\text { diedit, dan dihapus }\end{array}$ & $\mathrm{OK}$ \\
\hline 9 & $\begin{array}{l}\text { ! Input Data } \\
\text { Grup }\end{array}$ & $\begin{array}{l}\text { Admin melakukan input data } \\
\text { kontak }\end{array}$ & $\begin{array}{l}\text { Admin dapat menambah, mengedit, } \\
\text { dan menghapus data kontak }\end{array}$ & $\mathrm{OK}$ \\
\hline 10 & $\begin{array}{l}\text { Kelola data } \\
\text { pengaturan }\end{array}$ & $\begin{array}{l}\text { Admin melakukan input data } \\
\text { pengaturan }\end{array}$ & $\begin{array}{l}\text { Admin dapat menambah. mengedit, } \\
\text { dan menhapus data pengaturan }\end{array}$ & $\mathrm{OK}$ \\
\hline 11 & Fingerpint & $\begin{array}{l}\text { Siswa melakukan input } \\
\text { fingerprint }\end{array}$ & Siswa Dapat melakukan fingerprint & $\mathrm{OK}$ \\
\hline
\end{tabular}

Sumber: Hasil Penelitian (2020) 


\section{Kesimpulan}

Sistem presensi peserta didik pada SMK Globa Teknologi mampu meningkatkan kualitas informasi kehadiran peserta didik. Informasi dapat diterima dengan benar dan tepat waktu. Siste ini mampu memberikan informasi secara real-time kepada orang tua siswa dan wali kelas melalui sms gateway. Diharapkan sistem ini dapat dipelihara dengan baik oleh manajemen sekolah sehingga dapat digunakan secara terus menerus.

\section{Daftar Pustaka}

Apriliani, D., Wiyono, S., \& Mahardhika, S. (2018). Penerapan Metode Weighted Product Untuk Sistem Pendukung Keputusan Penerima Beasiswa Politeknik Harapan Bersama Tegal, 03(02), 136-142.

Munir, M. U., Javed, M. Y., \& Khan, S. A. (2012). A hierarchical k-means clustering based fingerprint quality classification. Neurocomputing, 85, 62-67. http://doi.org/10.1016/j.neucom.2012.01.002

Purnomo, R., \& Arisandi, P. R. (2019). Analisis QoS dengan Virtual Tenant Network pada Softwar Define Networking. Jurnal Teknologi Informatika Dan Komputer, 5(2).

Purnomo, R., Priatna, W., \& Fathurrozi, A. (2019). Perbandingan Logika Fuzzy dan Analytic Hierarchy Process untuk Menilai Kinerja Dosen, XIV(1), 48-59.

Sektiawan, A. (2016). Assessment of Work Behavior of Civil Servants in The Faculty of Mathematics ond Natural Sciences, Sebelas Maret University using Mamdani Fuzzy Inference System, 5(1), 50-56.

Supriyono, H., Kurnianto, A., \& Fikri Khaidir, M. (2018). Model Logika Fuzzy Sugeno Berbasis Web Untuk Seleksi Penerima Beasiswa. ISSN Jurnal IImiah SINUS, 16(1), 1693-1173. 